\title{
平成23年台風12号による三重県熊野酸性火成岩類における 土砂災害の状況報告
}

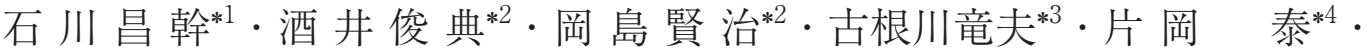 \\ 阪口和 $之^{* 5} \cdot$ 中谷 仁*6 長谷川謙二*7 ·林 健二*8 $\cdot$ 由 井 恒彦*9
}

平成23年 9 月に来襲した台風12号により三重県東紀州地域では多数の斜面崩壊が発生した。斜面崩壊の状況について崩壊前後の空中写 真, 地質図, DEMデータをもとに整理した結果, 全崩壊箇所 290 箇所のうち, 全体の約 $90 \%$ が熊野酸性火成岩類分布域で発生していた. 崩壊箇所の斜面の向きは，多くの崩壊が南東から南西の南向きに集中し，斜面勾配は，熊野酸性火成岩類南岩体では $30 \sim 40^{\circ}$ ，熊野酸性 火成岩類北岩体では35〜 $45^{\circ} に$ 集中していた。また，崩壊箇所の崩壊前の斜面の水平断面形は，谷型斜面 $47 \%$ ，直線斜面 $48 \%$ であるのに 対し, 尾根型斜面が $5 \%$ と発生は少なかった。現地調查を実施した箇所では, 崩壊は $\mathrm{D}_{\mathrm{L}} \sim \mathrm{D}_{\mathrm{M}}$ 級岩盤あるいは崖錐堆積物と $\mathrm{D}_{\mathrm{H}}$ 級岩盤との 境界を崩壊面として発生しており，崩壊地の一部では，崩壊面はシーティング節理沿いに形成されていた。また，その他の崩壊地では， 柱状節理に谷側への傾斜が確認され重力変形が顕著な箇所で生じたと考えられた。崩壊面の一部では，湧水が確認された。節理沿いの $\mathrm{D}_{\mathrm{H}}$ 級岩盤の透水係数は $10^{-5} \sim 10^{-6} \mathrm{~m} / \mathrm{s}$ 程度であるとともに, 湧水の電気伝導度は $3 \sim 4 \mathrm{mS} / \mathrm{m}$ と低く, 斜面崩壊に降雨時の浅層地下水が 関与していると考えられた.

Key words : 斜面崩壊 landslide, 空中写真 an aerial photograph, 熊野酸性火成岩類 Kumano Acidic Rocks

\section{1.は じめに}

三重県内では，平成23年 9 月に来襲した台風12号により， 県南部を中心に河川の増水・汇濫による家屋の浸水, 農地 の冠水, 河川護岸の浸食等の被害とともに, 斜面崩壊, 土 石流が多数発生した，特に東紀州地域では，比較的表層の 斜面崩壊が各所で多数確認された ${ }^{1)}$.

豪雨時の斜面崩壊の内，花崗岩分布域で崩壊が発生した 事例としては1972年の西三河豪雨災害 ${ }^{2), 3)}$ がある。矢入ら ${ }^{2)}$ は, 愛知県北部において花崗岩が分布する地域と花崗閃緑 岩が分布する地域の比較を行い, 花崗閃緑岩が分布する地 域と比べて花崗岩が分布する地域の方が崩壊密度が大きい ことを報告している。また, 戸邊ら ${ }^{3)}$ は, 崩壊の分布・密

*1 東邦地水 (株) Toho Chisui Co., Ltd. (会員)

*2 三重大学 Mie University

*3 御浜町役場 Mihama Town Office

*4 (株)キンキ地質センター Kinki Geo-Engineering Center Co., Ltd.

* 5 アジア航測(株) Asia Air Survey Co., Ltd. (会員)

*6 (株) 日さく Nissaku Co., Ltd.

*7 玉野総合コンサルタント(株) Tamano Consultants Co., Ltd.

*8 (株)フォレストエンジニアリング Forest engineering Co., Ltd.

*9 松阪鏊泉 (株) Matsusaka Sakusen Co., Ltd. (会員)
度に対する岩相と降雨の影響を数值的に詳細に検討し，花 崗岩地域の崩壊密度は293箇所/ $\mathrm{km}^{2}$ であり，花崗閃緑岩の 13箇所 $/ \mathrm{km}^{2}$ を一桁以上上回ったことを指摘し, この差は, 岩相間で風化帯構造が異なることによると推定している. 豪雨災害のうち, 花崗岩類と他の地質が分布する地域での 災害事例としては1967年の新潟県北東部から山形県南部に かけて発生した羽越豪雨災害が挙げられる。この災害では, 斜面崩壊の発生は花崗岩山地に多く, 中・古生界山地では 少なく, 発生頻度に大きな差がみられたことが指摘されて いる ${ }^{4)}$.

本報告は，新第三紀の火山-深成複合岩体である熊野酸 性火成岩類および新第三紀堆積岩の熊野層群が分布してい る地域のうち，東紀州地域の尾鷲市から紀宝町を対象に多 数発生した斜面崩壊に的を絞り, 斜面崩壊前後の空中写真, 地質図，DEMデー夕等をもとに整理した。また，現地調 査を実施し，崩壊状況について整理を行った。

\section{2. 対象地域の地質および調査の方法}

三重県南部の東紀州地域の尾鷲市から紀宝町にかけての 地域では台風12号の来襲により多数の斜面崩壊が発生した これらの崩壊が多数発生した地域の地質は, 図-1に示すよ うに熊野酸性火成岩類の花崗斑岩, 流紋岩類および新第三 紀堆積岩の熊野層群から構成されている5)。このうち熊野 


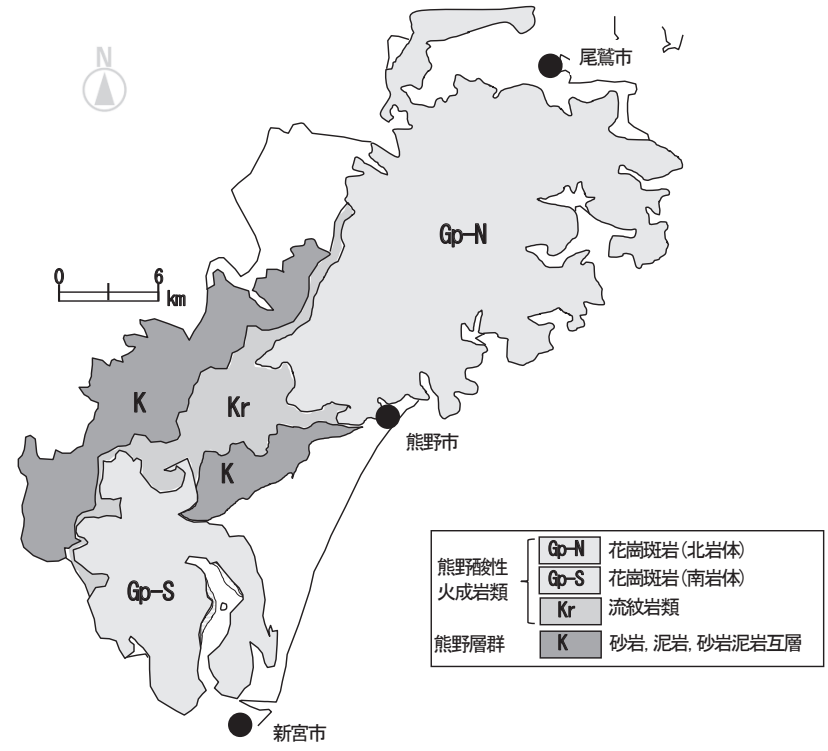

図-1東紀州地域の地質5),6)を基に作成

酸性火成岩類の花崗斑岩は, 大きく北側の北岩体と南側の 南岩体に区分される ${ }^{6}$.

本報では，三重県デジタル地図を用い，台風12号による 崩壊発生前後の空中写真を比較し崩壊箇所の抽出を行った

その上で，地質ごとの崩壊箇所数，崩壞前の斜面勾配， 崩壊が発生した斜面の向き, 崩壊が発生した斜面の水平断 面形》を整理した。また，現地調査を実施し，斜面崩壊発 生の素因について整理を行った。

\section{3. 結 果 と 考 察}

\section{1 地質と崩壊箇所数の関係}

図-2に崩壤前の平成19年のDEMデータ抢よび空中写真

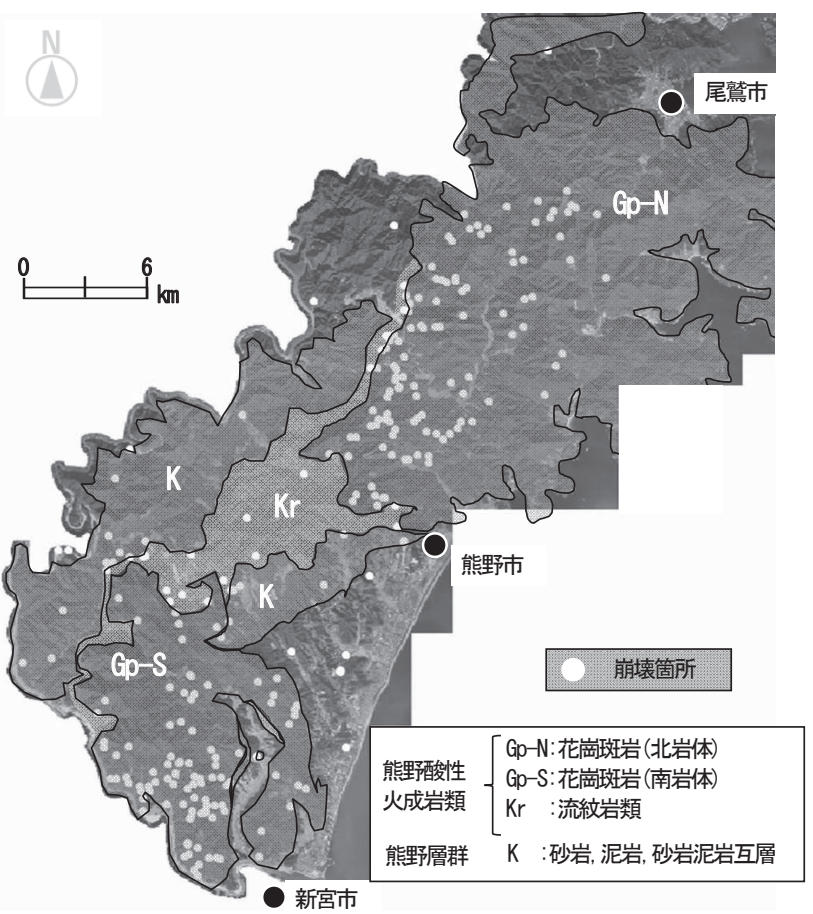

図-2 台風12号により発生した崩壊箇所と地質との対比図
と崩壊発生後の平成23年の空中写真との比較により崩壊箇 所を抽出し，東紀州地域の地質分布図に重ね合わせたもの を示す，崩壞箇所は白点で示した，崩壞箇所は，調查対象 とした熊野酸性火成岩類抒よび熊野層群において290箇所 を抽出した

表-1に地質毎の崩壞箇所数および $1 \mathrm{~km}^{2}$ あたりの崩壊発 生数を示す，崩壊箇所は，熊野層群では28箇所と全体の約 $10 \%$ で発生しており, 熊野酸性火成岩類では262箇所と全 体の $90 \%$ で発生している。また, 熊野酸性火成岩類のうち, 流紋岩類では27箇所と発生が少ないのに対し，花崗斑岩の 北岩体と南岩体ではそれぞれ118箇所，117箇所であり全体 の $80 \%$ 以上を占める.

$1 \mathrm{~km}^{2}$ あたりの崩壊発生密度は, 熊野層群は0.1箇所/ $\mathrm{km}^{2}$ と低い。熊野酸性火成岩類では流紋岩類で 0.44 箇所/ $\mathrm{km}^{2}$ ，花崗斑岩北岩体で 0.41 筒所 $/ \mathrm{km}^{2}$ に対し，南岩体では 1.06箇所 $/ \mathrm{km}^{2}$ と大きい傾向がある。

\section{表-1＼cjkstart地質毎の崩壊箇所数および割合}

\begin{tabular}{|c|c|c|c|c|c|c|}
\hline \multicolumn{2}{|r|}{ 地質 } & \multicolumn{2}{|c|}{ 箇所数 } & \multicolumn{2}{|c|}{ 割合(\%) } & 箇所 $/ \mathrm{km}^{2}$ \\
\hline \multirow{3}{*}{$\begin{array}{l}\text { 熊野酸性 } \\
\text { 火成岩類 }\end{array}$} & 花崗斑岩 (北岩体) & 118 & \multirow{3}{*}{262} & $40.7 \%$ & \multirow{3}{*}{$90.3 \%$} & 0.41 \\
\hline & 花崗斑岩(南岩体) & 117 & & $40.3 \%$ & & 1.06 \\
\hline & 流紋岩類 & 27 & & $9.3 \%$ & & 0.44 \\
\hline & 熊野層群 & \multicolumn{2}{|c|}{28} & \multicolumn{2}{|c|}{$9.7 \%$} & 0.10 \\
\hline
\end{tabular}

\section{2 崩壊が発生した斜面の向き}

崩壞が発生した斜面の向きは，図-3に示すように南東か ら南西の南方向が多い傾向があるため, 抽出した崩壊地の 斜面の向きについて整理を行った。

図-4および表-2に地質毎の崩壊地の斜面の向きを示す いずれの地質に扔いても南向き斜面で崩壊が多く発生し ている. 南東から南西にかけての南向き斜面に扔ける崩壊 は, 熊野層群では $61 \%$, 熊野酸性火成岩類の流紋岩類で $74 \%$ ，花崗斑岩南岩体で87\%，北岩体で80\%であった。

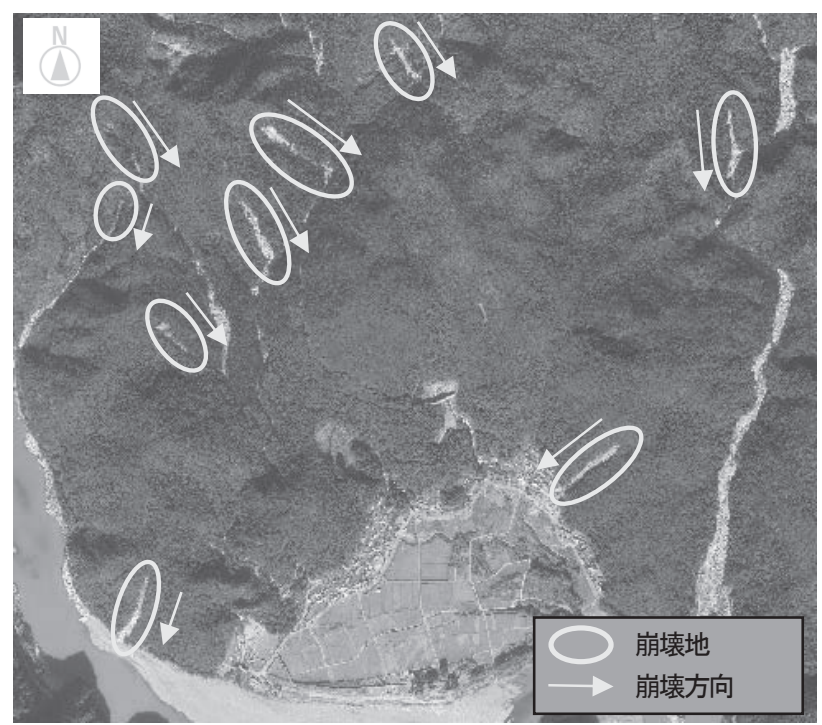

図-3＼cjkstart花崗斑岩（南岩体）での崩壊方向 


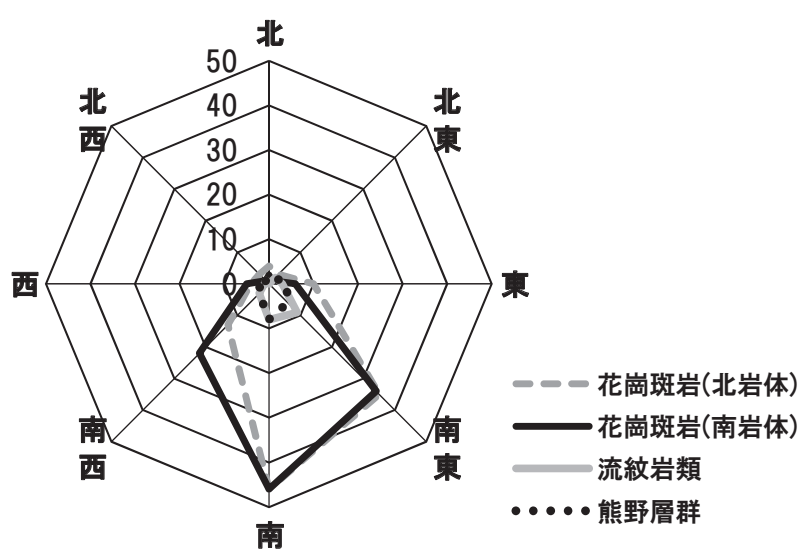

図-4 地質毎の崩壊地の斜面の向き整理結果

表-2 地質毎の崩壊が発生した斜面の向き

\begin{tabular}{|c|c|c|c|c|c|c|c|c|c|c|}
\hline \multirow{2}{*}{\multicolumn{2}{|c|}{ 地質 }} & \multicolumn{8}{|c|}{ 崩壊が発生した斜面の向き(割合) } & \multirow{2}{*}{ 合計 } \\
\hline & & 北 & 北東 & 東 & 南東 & 南 & 南西 & 西 & 北西 & \\
\hline \multirow{6}{*}{ 熊野酸性 } & \multirow{2}{*}{$\begin{array}{l}\text { 花崗斑岩 } \\
\text { (北岩体) }\end{array}$} & \multirow{2}{*}{$3 \%$} & \multirow{2}{*}{$3 \%$} & \multirow{2}{*}{$8 \%$} & $30 \%$ & $39 \%$ & $11 \%$ & \multirow{2}{*}{$3 \%$} & \multirow{2}{*}{$3 \%$} & \multirow{2}{*}{$100 \%$} \\
\hline & & & & & \multicolumn{3}{|c|}{$80 \%$} & & & \\
\hline & \multirow{2}{*}{$\begin{array}{l}\text { 花崗斑岩 } \\
\text { (南砳体) }\end{array}$} & \multirow[t]{2}{*}{$2 \%$} & \multirow[t]{2}{*}{$1 \%$} & \multirow[t]{2}{*}{$5 \%$} & $29 \%$ & $39 \%$ & $19 \%$ & \multirow[t]{2}{*}{$4 \%$} & \multirow[t]{2}{*}{$1 \%$} & $100 \%$ \\
\hline & & & & & & $87 \%$ & & & & \multirow{3}{*}{$100 \%$} \\
\hline & \multirow{2}{*}{ 流紋岩類 } & \multirow{2}{*}{$0 \%$} & \multirow[t]{2}{*}{$7 \%$} & \multirow{2}{*}{$11 \%$} & $33 \%$ & $30 \%$ & $11 \%$ & \multirow{2}{*}{$4 \%$} & $4 \%$ & \\
\hline & & & & & & $74 \%$ & & & & \\
\hline \multicolumn{2}{|c|}{ 熊野層群 } & $7 \%$ & $7 \%$ & $14 \%$ & $21 \%$ & $29 \%$ & $11 \%$ & $7 \%$ & $4 \%$ & $100 \%$ \\
\hline
\end{tabular}

\section{3 崩壊前の斜面勾配}

図-5に示すように，崩壊地頭部付近における崩壊前の斜 面勾配を平成19年度作成の $5 \mathrm{~m}$ メッシュ DEMデータを用 いて整理した。

図-6に地質毎に整理した結果を示す。崩壊が発生した箇 所の崩壊地頭部における崩壊前の斜面勾配は, 熊野層群, 熊野酸性火成岩類のうち, 流紋岩類および花崗斑岩南岩体 では30〜 40 , 花崗斑岩北岩体では35〜45 の頻度が高く, 花崗斑岩北岩体は南岩体と比較して 5 〜 $10^{\circ}$ 急な斜面で崩 壊が発生している。

\section{4 崩壊地の斜面の水平断面形}

崩壊箇所について, 豪雨時の斜面表層への雨水の浸透が
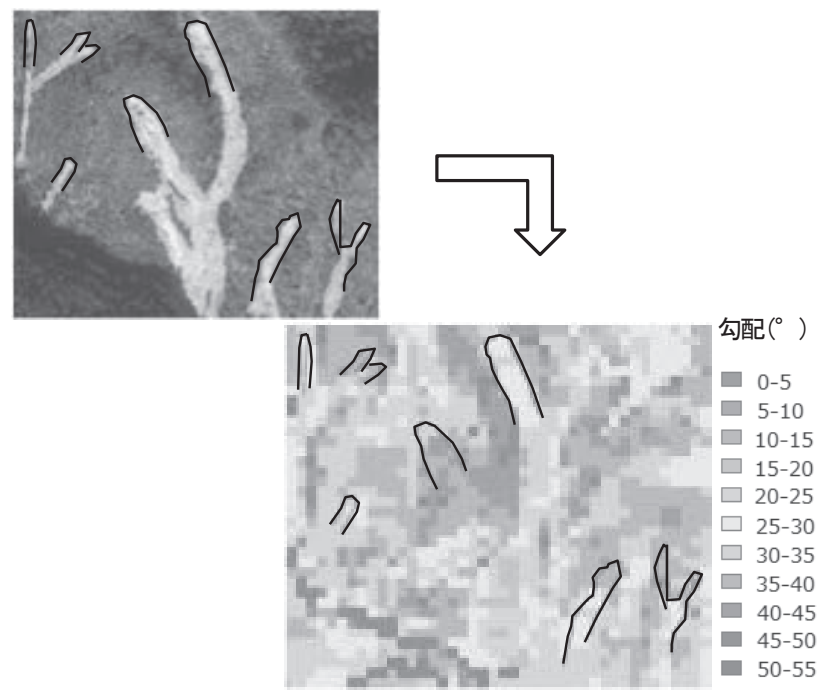

図-5＼cjkstart崩壊地頭部付近の斜面勾配の求め方

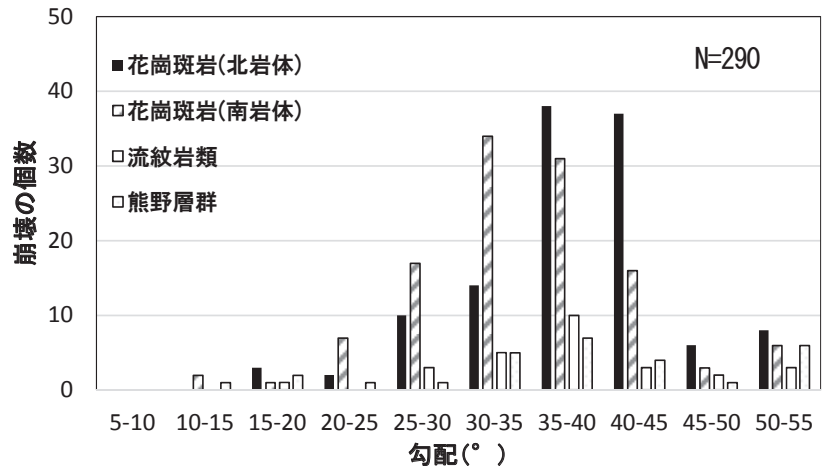

図-6＼cjkstart地質毎の崩壊地頭部付近の斜面勾配の整理結果

考えられた。そこで，平成19年のDEMデータをもとに， 鈴木 $(1997)^{7)}$ に基づき崩壊前の斜面の水平断面形を分類 した。図ー7に空中写真の対比により判読した崩壊地を，崩 壊前の等高線を用いて水平断面形の谷型斜面，尾根型斜面， 直線斜面に分類した例を示す。また，その分布結果を表-3 に示す。崩壊地の地形は $47 \%$ が谷型斜面， $49 \%$ が直線斜面 であるのに対し，尾根型斜面での発生は $5 \%$ と少ない.

\section{5 現地調査結果}

$1 \mathrm{~km}^{2}$ あたり1.06箇所と崩壊発生頻度が高い熊野酸性火 成岩類の花崗斑岩南岩体を対象に現地調査を実施した。現 地調査は，図-8に示す小鹿川および大和田川の源頭部で発 生した崩壊規模が比較的大きく，崩壊深が異なる 2 箇所を

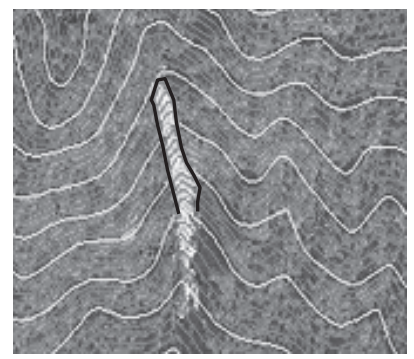

谷型斜面

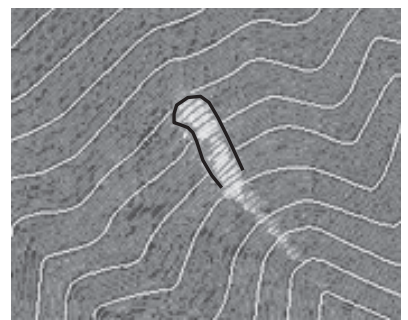

直線斜面

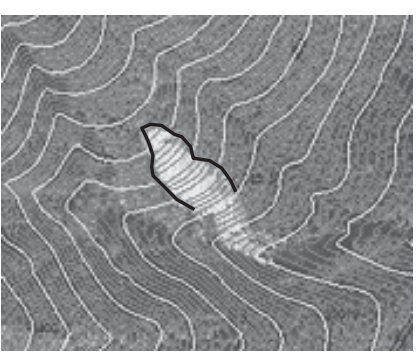

尾根型斜面
図-7 崩壊地の地形状況（水平断面形）

表-3 崩壊地の地形（水平断面形）別箇所数一覧表

\begin{tabular}{|c|c|c|c|c|}
\hline \multirow{2}{*}{\multicolumn{2}{|c|}{ 地質 }} & \multicolumn{3}{|c|}{ 地形 (水平断面形) } \\
\hline & & 谷型斜面 & 尾根型斜面 & 直線斜面 \\
\hline \multirow{3}{*}{$\begin{array}{l}\text { 熊野酸性 } \\
\text { 火成岩類 }\end{array}$} & 花崗斑岩 (北岩体) & 62 & 0 & 56 \\
\hline & 花崗斑岩 (南岩体) & 52 & 8 & 57 \\
\hline & 流紋岩類 & 13 & 3 & 11 \\
\hline \multicolumn{2}{|r|}{ 熊野層群 } & 8 & 3 & 17 \\
\hline \multirow{2}{*}{ 合計 } & 箇所数 & 135 & 14 & 141 \\
\hline & 割合 (\%) & $47 \%$ & $5 \%$ & $49 \%$ \\
\hline
\end{tabular}




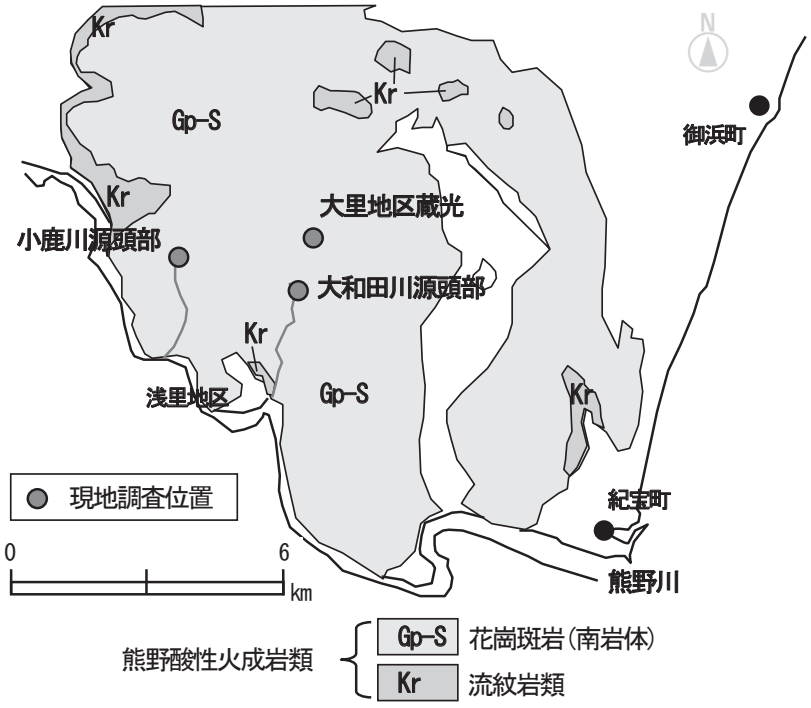

図-8 現地調查位置図 ${ }^{5 \text { を基に作成 }}$

表-4 現地調査時に使用した岩盤分類息を基に作成

\begin{tabular}{|c|c|}
\hline 岩級区分 & 風化変質, 硬軟の程度 \\
\hline $\mathrm{D}_{\mathrm{L}}$ & $\begin{array}{l}\text { 手の平ての指圧砕でおおむね粉末状となる. 一部, 砂状となる. } \\
\text { 長石類はほんしと啠質, 粘土化, 石英は細粒化している. }\end{array}$ \\
\hline$D_{M}$ & 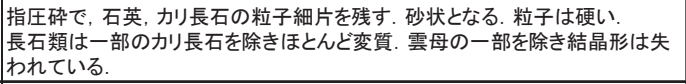 \\
\hline$D_{H}$ & $\begin{array}{l}\text { 指圧砕て，ようやくつぶれる. 粒子は硬く磷状〜砂状を呈している. } \\
\text { 部石類の大分は変質. 雲母の黄金色化が見られ，粘辺土化 }\end{array}$ \\
\hline$c_{L}$ & 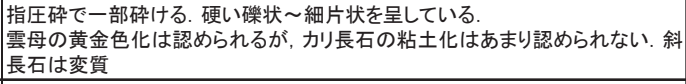 \\
\hline $\mathrm{C}_{\mathrm{M}}$ & $\begin{array}{l}\text { 分マーで軽くたたたいて割れる. } \\
\text { 斜長石の変質進む. }\end{array}$ \\
\hline $\mathrm{C}_{\mathrm{H}}$ & $\begin{array}{l}\text { 岩片はわりあい硬啠 } \\
\text { 斜長石, 黒雲母は若干変質 }\end{array}$ \\
\hline
\end{tabular}

対象とした。 あわせて，大里地区蔵光では， $\mathrm{D}_{\mathrm{H}}$ 級岩盤（表 -4参照）を対象に透水係数の確認を目的として試料採取を 行い土質試験を実施した，現地調査での風化区分は表-4に 示すD級岩盤が 3 段階で分類されている本州四国連絡橋公 団の岩盤分類 ${ }^{8}$ を用いた，花崗斑岩は，風化が進行してい る箇所では, 球状風化しコアストーンが形成されている場 合が多い，そのため, 現地調査での風化区分は, コアストー ン間の風化部をもとに判定を行った。また, これら 3 地点 に対し, 平成23年 9 月の災害より前の空中写真で確認を 行った結果，明暸な旧崩壊地は確認できなかった。このこ とから，現地調查を実施した崩壊地は旧崩壊地が拡大した ものではないと考元らえる.

\subsection{1 小鹿川源頭部崩壊地}

図-9に小鹿川源頭部崩壊地の平面図を, 図-10に断面図 を示す，崩壊地頭部は稜線に近い位置にある遷急線の付近

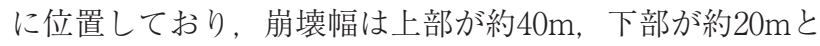

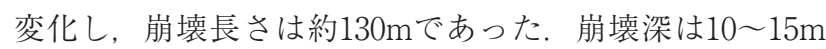
であることを確認した。

崩壊地を構成する主な地質は, 熊野酸性火成岩類の花崗

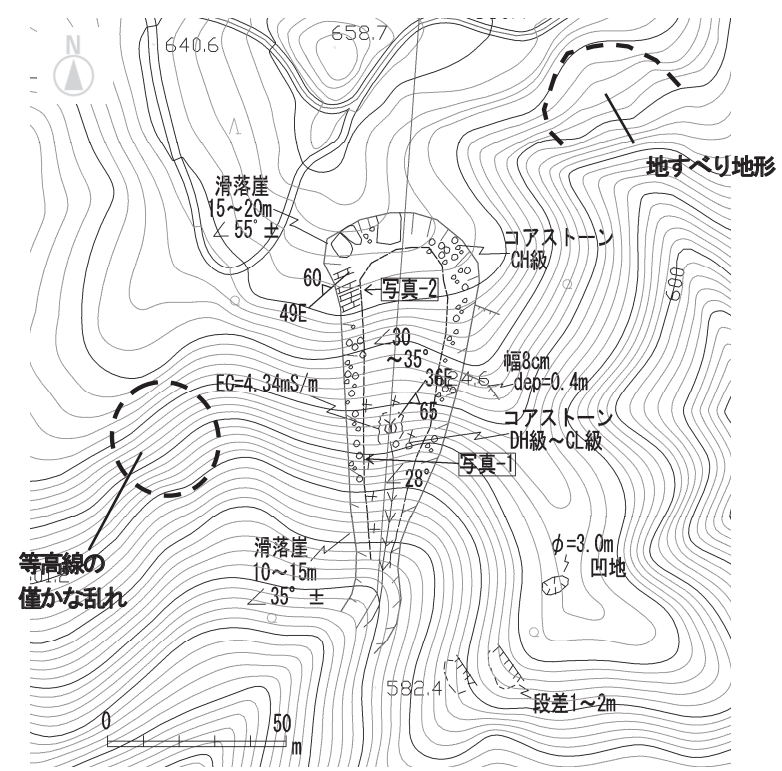

図-9 小鹿川源頭部 崩壊地平面図

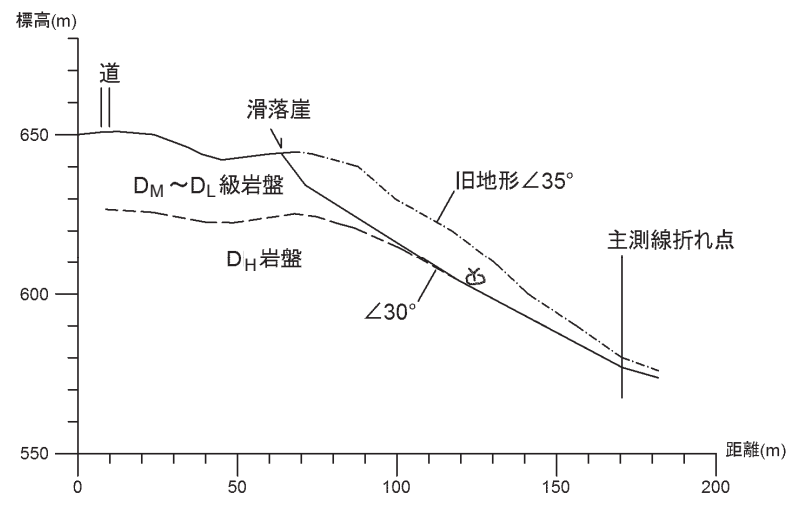

図-10 小鹿川源頭部 崩壊地断面図

斑岩であり，後述するように風化しているため不明膫では あるが流紋岩類が分布している可能性もある。崖錐堆積物 は確認されなかった。斜面勾配は, 崩壊前が約 $35^{\circ}$ であり, 崩壊後の崩壊面では約 $30^{\circ}$ となっていた，現地状況の確認 では, 崩壊面は崩壊地上部に打いては $\mathrm{D}_{\mathrm{M}}$ 級岩盤（地表付 近は $\mathrm{D}_{\mathrm{L}}$ 級岩盤）内にあるものの，中部から下部にかけて は $\mathrm{D}_{\mathrm{M}}$ 級岩盤と $\mathrm{D}_{\mathrm{H}}$ 級岩盤の境界付近であった。 写真-1に示

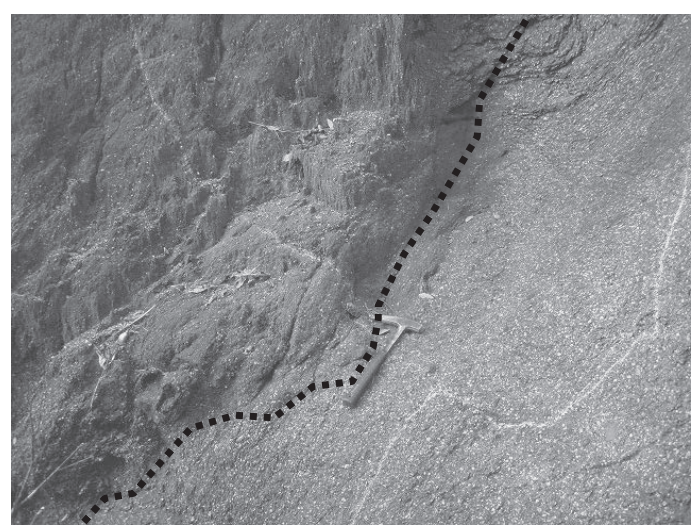

写真-1 崩壊地底部（点線部分（ハンマー付近）が $\mathrm{D}_{\mathrm{M}}$ 級岩盤と $D_{\left.\text {H級岩盤の境界，勾配約 } 30^{\circ}\right)}$ 


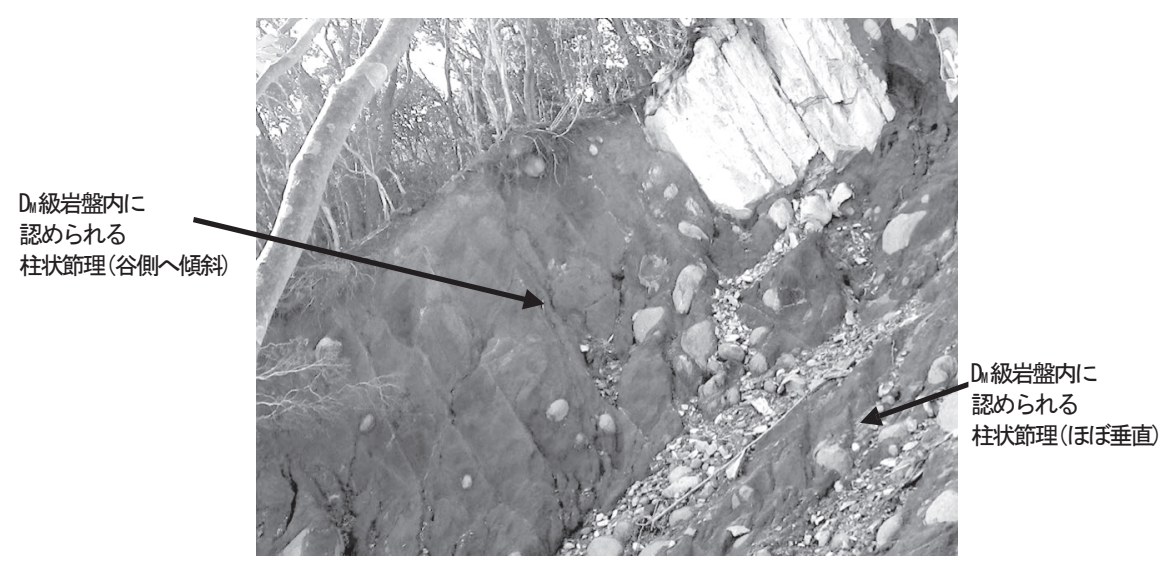

写真-2＼cjkstart崩壊地側部（ $D_{\mathrm{M}}$ 級岩盤内の柱状節理）

盤主体であり，一部が崖錐堆積物か ら構成される。崩壊面は, 崩壊地上 部では $\mathrm{D}_{\mathrm{L}}$ 級岩盤内にあり，上部か ら中部にかけては， $\mathrm{D}_{\mathrm{L}} \sim \mathrm{D}_{\mathrm{M}}$ 級岩盤 と $\mathrm{D}_{\mathrm{H}}$ 級岩盤の境界であった。また, 崩壊地下方の道路との交差部付近で は花崗斑岩の $\mathrm{C}_{\mathrm{M}} \sim \mathrm{C}_{\mathrm{H}}$ 級岩盤が露頭 しており柱状節理が見られる。ささら に，崩壊地下方の花崗斑岩の $\mathrm{C}_{\mathrm{M}} \sim$ $\mathrm{C}_{\mathrm{H}}$ 級岩盤が分布する付近では, 一 部, 流紋岩質凝灰岩が確認されるこ とから, 崩壊地周辺は花崗斑岩と流

すように $\mathrm{D}_{\mathrm{M}}$ 級岩盤と $\mathrm{D}_{\mathrm{H}}$ 級岩盤の境界の勾配は約 $30^{\circ}$ と崩 壊面の勾配と一致している。 $\mathrm{D}_{\mathrm{M}}$ 級岩盤は, 主に径 1 $2 \mathrm{~m}$ 硬質なコアストーンが多量に確認された。なお, $\mathrm{D}_{\mathrm{M}}$ 級岩盤の一部では写真-2に示すように柱状節理が確認 された。しかし，下位の $\mathrm{D}_{\mathrm{H}}$ 級岩盤では確認できなかった また, $\mathrm{D}_{\mathrm{H}}$ 級岩盤では岩相が一部, 細粒状の凝灰岩質とな り凝灰岩の岩片も認められた。風化が進行しており不明瞭 ではあるが， $\mathrm{D}_{\mathrm{H}}$ 級岩盤を構成する地質は流紋岩類である 可能性が考えられる。 $\mathrm{D}_{\mathrm{M}}$ 級岩盤内で確認された柱状節理 は, 写真-2に示すように $\mathrm{D}_{\mathrm{M}}$ 級岩盤と $\mathrm{D}_{\mathrm{H}}$ 級岩盤境界付近で は垂直であるが，地表にかけて谷側に傾斜しており， $\mathrm{D}_{\mathrm{M}}$ 級岩盤内で岩盤クリープが進行していた可能性がある。ま た, 図-9に示すように, 崩壊地周辺では等高線の乱れや, 地すべり地形が判読できる。なお，小鹿川源頭部では，崩 壊地中腹部の $\mathrm{D}_{\mathrm{L}} \sim \mathrm{D}_{\mathrm{M}}$ 級岩盤と $\mathrm{D}_{\mathrm{H}}$ 級岩盤の境界付近におい て湧水が確認された。

\subsection{2 大和田川源頭部}

図-11に大和田川源頭部崩壊地の平面図を, 図-12に断面 図を示す，崩壊地の崩壊幅は上部が約 $20 \mathrm{~m}$ ，下部が約 $60 \mathrm{~m}$ と変化し, 崩壊長さは約 $300 \mathrm{~m}$ とっている。また, 崩壊 深は $2 \sim 7 \mathrm{~m}$ 程度で, 斜面勾配は崩壊前後共に上部が約 $40^{\circ}$ ，下部は約 $30^{\circ}$ となっていた.

崩壊地は, 熊野酸性火成岩類の花崗斑岩の $\mathrm{D}_{\mathrm{L}} \sim \mathrm{D}_{\mathrm{M}}$ 級岩

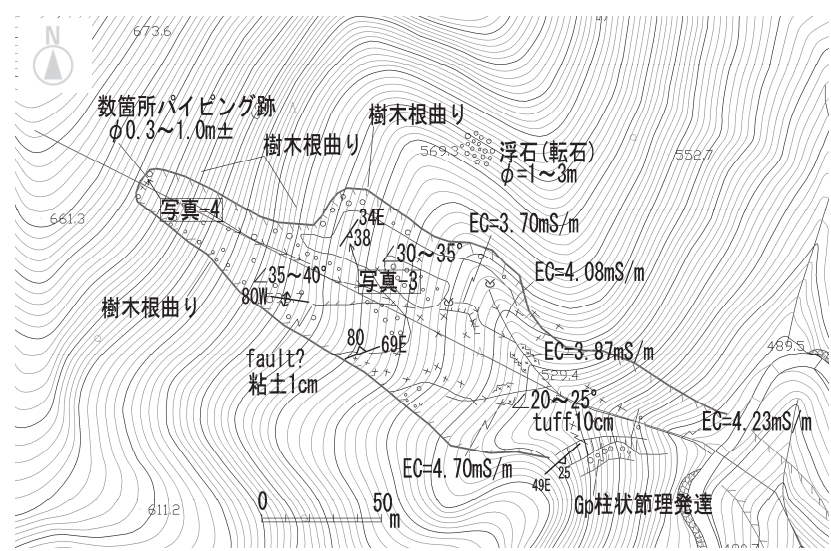

図-11 大和田川源頭部 崩壊地平面図
紋岩類の境界付近に位置していると考えられる。また，崩 壊地中部付近において写真-3に示すようなシーティング節 理が崩壊面付近の $\mathrm{D}_{\mathrm{H}}$ 級岩盤で確認できる。シーティング 節理の走向は北東-南西方向で傾斜方向はほほ崩壊方向と 一致し流れ盤構造を呈しており，その傾斜は30～35を示 す. 崩壊地中部から上部にかけては, 径が1.0〜 2.0m前後 の硬質なコアストーンを含む $\mathrm{D}_{\mathrm{L}} \sim \mathrm{D}_{\mathrm{M}}$ 級岩盤から構成され ており, 崩壊地頭部の高さ約 $2 \mathrm{~m}$ の滑落崖においては, 径 数 $\mathrm{cm}$ のパイピング跡が確認され, 最大では写真-4に示す

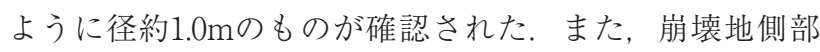
および上部の植林地の一部で根曲りを確認した。なお，大

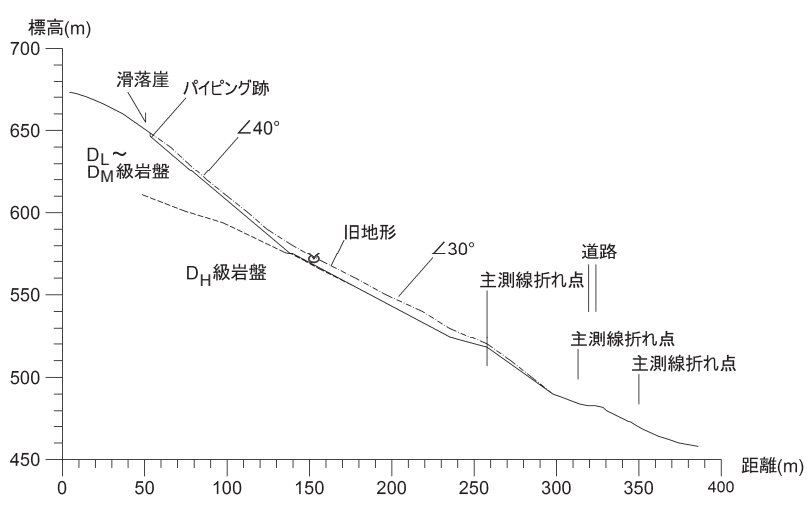

図-12 大和田川源頭部 崩壊地断面図

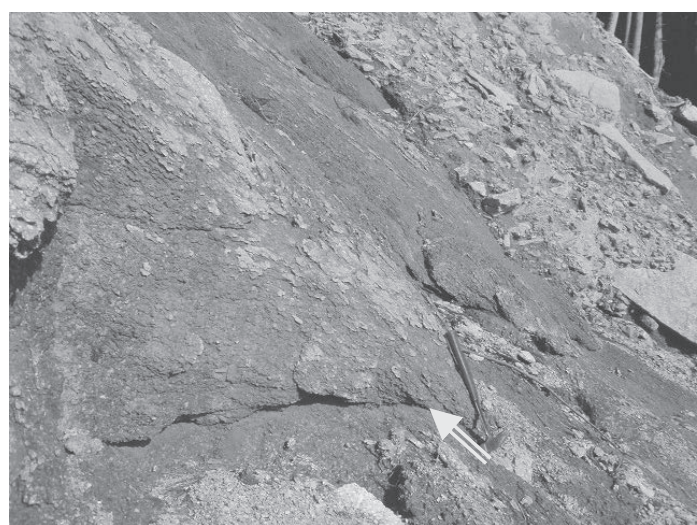

写真-3 崩壊地中腹（風化部のシーティング節理, 崩壊面に対し 流れ盤となる.) 


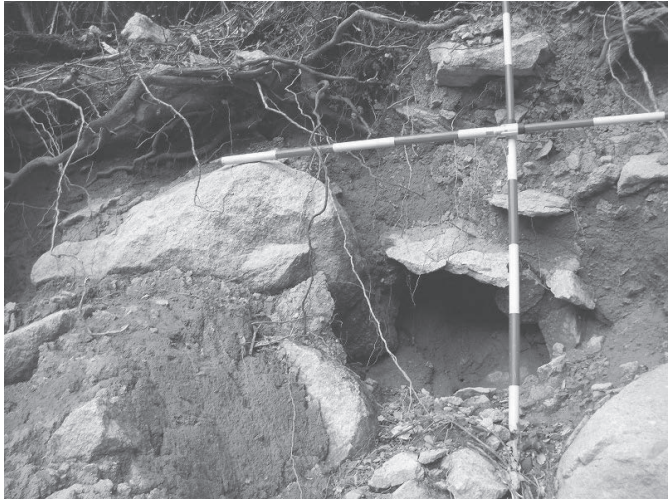

写真-4 崩壊地頭部 (パイピング跡 (最大径約 $1.0 \mathrm{~m})$ が確認される) 和田川源頭部では, 崩壊地中腹部の $\mathrm{D}_{\mathrm{L}} \sim \mathrm{D}_{\mathrm{M}}$ 級岩盤と $\mathrm{D}_{\mathrm{H}}$ 級 岩盤の境界付近において湧水が確認された。

\subsection{3 大里地区藏光}

図-13に大里地区蔵光の平面図を示す。崩壊地の崩壊幅 は40m程度であり，崩壊面では花崗斑岩の $\mathrm{D}_{\mathrm{H}}$ 級岩盤 $\mathrm{C}_{\mathrm{M}}$ 級岩盤が確認された，崩壊面は，崩壊面側部〜上部に露出 している $\mathrm{D}_{\mathrm{M}}$ 級岩盤 $\sim \mathrm{C}_{\mathrm{L}}$ 級岩盤の節理の分布状況から, シー ティング節理沿いに形成され，その上位の $\mathrm{D}_{\mathrm{L}} \sim \mathrm{D}_{\mathrm{M}}$ 級岩盤 が崩壊したものと考えられる。

崩壊地頭部の滑落崖は, $\mathrm{D}_{\mathrm{L}} \sim \mathrm{D}_{\mathrm{M}}$ 級岩盤から構成されて おり，主に径 $2 \sim 4 \mathrm{~m}$ の硬質なコアストーンが多く確認さ れた，崩壊面であるシーティング節理の走向は北東-南西 方向でやや斜面の向きと斜交しており，谷側に約 $35^{\circ} て ゙$ 傾 斜し流れ盤構造となっている.

当地区の崩壊面に近いシーティング節理沿いの花崗斑岩

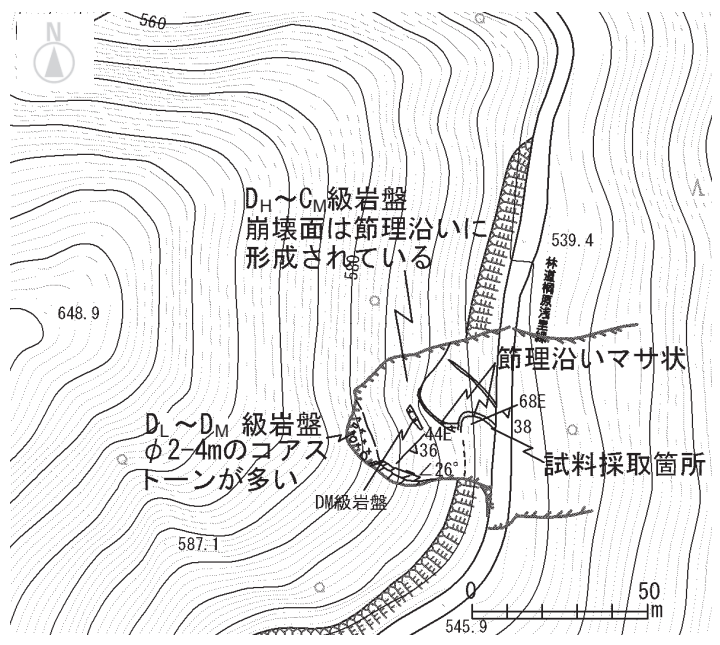

図-13 大里地区蔵光 崩壊地平面図
の $\mathrm{D}_{\mathrm{H}}$ 級岩盤を対象に物理試験および透水試験を行うため,

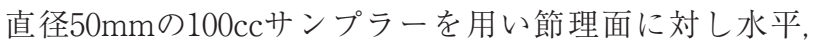
垂直方向に直接地盤に貫入させて試料を採取し室内試験を 実施した。試験結果を表-5に示す。粒度試験の結果，粗粒 分が80\%含まれ，土質材料の工学的分類体系 ${ }^{9}$ ではSF-Gに 分類される磁まじり細粒分質砂であった，室内透水試験の 結果, 透水係数は方向による差はなく，概ね $10^{-5}$ $10^{-6} \mathrm{~m} / \mathrm{sec}$ 程度であり, 表-6に示す一般值と比較すると「透 水性は低い」と判定される。なお，表-6では $10^{-5} \sim$ $10^{-6} \mathrm{~m} / \mathrm{sec}$ の場合, 微細砂〜シルトと判定され，一般的な 粒度試験結果から推定される值と異なる結果となった。

また，崩壊部と考えられる $\mathrm{D}_{\mathrm{M}}$ 級岩盤と $\mathrm{D}_{\mathrm{H}} \sim \mathrm{C}_{\mathrm{L}}$ 級岩盤の 境界である崩壊面付近では，現地調査時には湧水は確認さ れないものの湿潤状態となっている箇所が確認された。こ のことを考慮すると, 崩壊は, 難透水層と考えられる $\mathrm{D}_{\mathrm{H}}$ 級岩盤の上位の $\mathrm{D}_{\mathrm{L}} \sim \mathrm{D}_{\mathrm{M}}$ 級岩盤内の水の移動に伴う間隙水 圧の増加が誘因である可能性が考えられる.なお, シーティ ング節理沿いの花崗斑岩の $\mathrm{D}_{\mathrm{H}}$ 級岩盤の土質特性の評価に あたっては，今回の測定に加え今後他地点での検討が必要 と考えている.

\subsection{4 水文特性}

小鹿川源頭部および大和田川源頭部では，崩壊地中腹部 の $\mathrm{D}_{\mathrm{L}} \sim \mathrm{D}_{\mathrm{M}}$ 級岩盤と $\mathrm{D}_{\mathrm{H}}$ 級岩盤の境界付近において湧水が確 認された。崩壊発生の誘因として，斜面表層の地下水の影 響があることが推察される。そこで，崩壊箇所の湧水とそ の周囲の沢との電気伝導度を測定し，既往資料における雨 水, 本流である熊野川での電気伝導度と比較し, 崩壊地で の地下水の性状について確認を行った.

小鹿川源頭部および大和田川源頭部での崩壊地内の湧水 と, 崩壊地外周辺の沢水の電気伝導度の測定結果, 三重県 内の雨水，本流である熊野川での電気伝導度を表-7に示す 崩壊箇所内の湧水箇所では約 $4.0 \mathrm{mS} / \mathrm{m}$ と低い傾向を示す.

表-5＼cjkstart崩壊地内風化部の土質試験結果

\begin{tabular}{|c|c|c|c|c|c|c|}
\hline \multirow{2}{*}{\multicolumn{3}{|c|}{$\begin{array}{l}\text { 土粒子密度 } \\
\text { 含水比 }\end{array}$}} & $2.742 \mathrm{~g} / \mathrm{cm}^{3}$ & \multirow{4}{*}{ 透水係数 } & \multirow{2}{*}{ 水平方向 } & $1.58 \times 10^{-5} \mathrm{~m} / \mathrm{sec}$ \\
\hline & & & $21.47 \%$ & & & $4.47 \times 10^{-6} \mathrm{~m} / \mathrm{sec}$ \\
\hline \multirow{4}{*}{ 粒度 } & \multirow{2}{*}{ 粗粒土 } & 礫分 & $10 \%$ & & \multirow{2}{*}{ 垂直方向 } & $3.04 \times 10^{-6} \mathrm{~m} / \mathrm{sec}$ \\
\hline & & 砂分 & $70 \%$ & & & $1.46 \times 10^{-6} \mathrm{~m} / \mathrm{sec}$ \\
\hline & \multirow{2}{*}{ 細粒土 } & シルト & $6 \%$ & & & \\
\hline & & 粘土 & $14 \%$ & & & \\
\hline
\end{tabular}

表-6 透水係数と透水性の関係 ${ }^{9}$

透水係数 $\mathrm{k}(\mathrm{m} / \mathrm{s})$

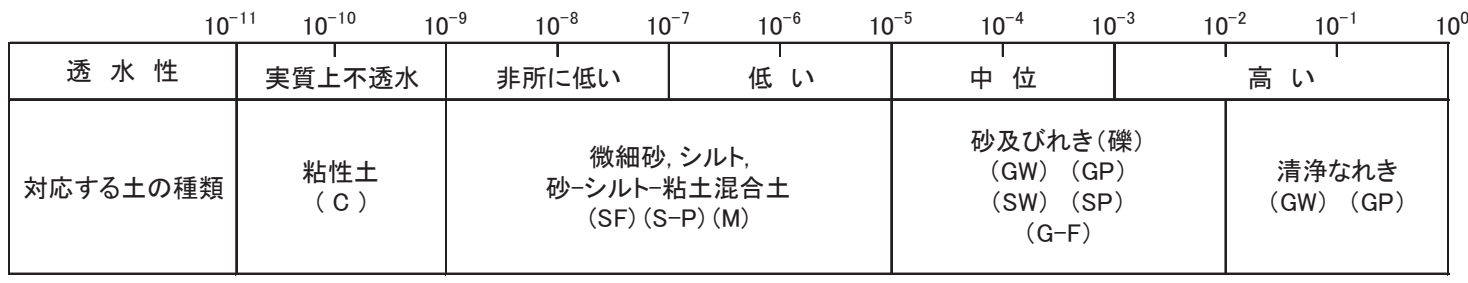




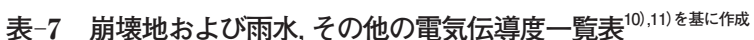

\begin{tabular}{|c|c|c|c|c|}
\hline 地域 & 地点 & 観測箇所 & $\begin{array}{c}\text { 電気伝導度 } \\
(\mathrm{mS} / \mathrm{m})\end{array}$ & 備考 \\
\hline \multirow{9}{*}{$\begin{array}{l}\text { 三 } \\
\text { 重 } \\
\text { 県 }\end{array}$} & 小鹿川源頭部 & 湧水 & 4.34 & \\
\hline & \multirow{5}{*}{$\begin{array}{c}\text { 大和田川 } \\
\text { 源頭部 }\end{array}$} & 湧水 & 4.23 & \\
\hline & & 湧水 & 4.70 & \\
\hline & & 湧水 & 3.87 & \\
\hline & & 湧水 & 4.08 & \\
\hline & & 湧水 & 3.70 & \\
\hline & \multirow{2}{*}{ 沢 (崩壊地以外) } & 沢 & 3.46 & \\
\hline & & 沢 & 3.99 & \\
\hline & 亀山市 & 雨水 & $0.6 \sim 11.2$ & 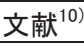 \\
\hline \multirow{3}{*}{$\begin{array}{l}\text { 和 } \\
\text { 歌 } \\
\text { 山 } \\
\text { 県 }\end{array}$} & \multirow{3}{*}{ 熊野川 } & 宮井橋 & 6.00 & \multirow{3}{*}{ 文献 ${ }^{11)}$} \\
\hline & & 三和大橋 & 6.00 & \\
\hline & & 熊野大橋 & 12.00 & \\
\hline
\end{tabular}

これは, 同じ三重県内の雨水での值と比較すると, 雨水の 中間值よりもやや低い值を示す。なお，大里地区では，現 地調査時には湧水は確認されないものの湿潤状態となって いる箇所が確認された。 このことから確認できた範囲では, 崩壊の誘因として浸透水起源の浅層地下水の可能性が考え られる。電気伝導度の評価に関しては, 今回の結果に加え、 今後測定箇所を増やして検討を行う必要があると考えてい る.

\section{4. おわりに}

平成23年台風12号により東紀州地域の尾鷲市から紀宝町 にかけ発生した斜面崩壊の状況について, DEMデータ, 空中写真, 地質図等をもとに整理した。また，崩壊発生頻 度が高い熊野酸性火成岩類の花崗斑岩南岩体のうち比較的 大きな崩壊であった 3 箇所を対象に現地調査を行い, 下記 の結果を得た。

・空中写真判読の結果, 熊野酸性火成岩類および熊野層群 における崩壊箇所は290箇所あり，そのうち熊野酸性火 成岩類で全体の $90 \%$ 以上を占めていた。また，熊野酸性 火成岩類のうち花崗斑岩南岩体および北岩体における発 生が全体の $80 \%$ 以上であった。

・崩壊が発生した斜面の向きは南東から南西の南向き斜面 における発生が多く, 熊野酸性火成岩類分布域の崩壊箇 所では約80\%を占めていた。

・崩壊前の崩壊箇所の斜面勾配は, 熊野層群, 熊野酸性火 成岩類のうち, 流紋岩類, 花崗斑岩南岩体では30 40 であるのに対し，花崗斑岩北岩体では $35 \sim 45^{\circ}$ と，花崗 斑岩北岩体は南岩体と比較して 5 〜 $10^{\circ}$ 急な斜面であっ た。

・崩壊箇所は, いずれの地質においても, 水平断面形で分 類した場合，尾根型斜面での発生は少なく，谷型斜面， 直線斜面での崩壊が90\%以上を占めていた.

・花崗斑岩南岩体 3 箇所での現地調査の結果, 崩壊面は $\mathrm{D}_{\mathrm{L}} \sim \mathrm{D}_{\mathrm{M}}$ 級岩盤と $\mathrm{D}_{\mathrm{H}}$ 級岩盤の境界付近および $\mathrm{D}_{\mathrm{L}} \sim \mathrm{D}_{\mathrm{M}}$ 級
岩盤内において形成されていた

・小鹿川源頭部では岩盤クリープと考えられる形跡が確認 でき，重力変形が顕著な箇所で崩壊が発生した可能性が 考えられる。

・大和田川源頭部では崩壊面付近ではシーティング節理が 確認でき，崩壊面はこのシーティング節理に沿って形成 されていた。

・大和田川源頭部での崩壊地では, 崩壊地頭部の $\mathrm{D}_{\mathrm{L}} \sim \mathrm{D}_{\mathrm{M}}$ 級岩盤には, 直径約数 $\mathrm{cm}$ のパイピング跡が複数存在す ることが確認できた

・現地調查を実施した小鹿川源頭部，大和田川源頭部では 湧水と雨水の電気伝導度とに大きな違いは無く, 浅層地 下水が崩壊の誘因と想定された。

・現地調查を実施した比較的大きな崩壊がみられた 3 箇所 の崩壊箇所においては，いずれも崩壊前の空中写真や地 形図において旧崩壊跡等は確認できず，今回の崩壊は旧 崩壊箇所の拡大ではないと考えられる.

今後はこれらの結果をもとに, 崩壊発生の素因について 検討を行い, 崩壊発生時の降雨特性も併せ, 南向き斜面に 崩壊が集中した原因について詳しく検討を行う必要がある と考える。なお，本報告の現地調査結果に基づく結果は熊 野酸性火成岩類の内, 花崗斑岩南岩体 3 箇所での確認事項 をもとに検討を行ったものであるため, 今後, 他地点を含 め測定箇所を増やし検討を行う必要があると考えている.

謝辞 本研究は, 地盤工学会関西支部「想定外」豪雨によ る地盤災害への対応を考える調査研究委員会」の支援を受 けました。また, 本研究の一部は,財団法人レントオール 奨学財団, 和歌山大学平成24-25年度独創的研究支援プロ ジェクト，および西日本旅客鉄道株式会社の支援を受けて 行われました。ささらに, 三重大学生物資源学部の学部生池 田静香さん, 大久保啓太君にはデー夕整理等にご尽力いた だきました。ここに深謝の意を表します。

\section{引用 文 献}

1）三重県（2012）：紀伊半島大水害一平成23年台風12号による 災害の記録.

2）矢入謙二・諏訪兼位・増岡康男 (1973)：47 · 7 豪雨に伴う山 崩れ一愛知県西加茂郡小原村・藤岡村の災害一, 科研費報告 書, pp.92-101.

3） 戸邊勇人 ·千木良雅弘 ·土志田正二（2007）：愛知県小原村 の風化花崗岩類における崩壊発生密度の岩相間での比較, 応 用地質, Vol.48, No.2, pp.66-79.

4）日本応用地質学会 (2000) : 山地の地形工学, 第1刷, 古今書 院, 44p.

5）独立行政法人 産業技術総合研究所/地質調查総合センター： 地質図表示システム地質図Navi, https://gbank.gsj.jp/ geonavi/, 2014年 6 月18日閲覧.

6）川上裕・星博幸（2007）：火山－深成複合岩体にみられる環 
状岩脈とシート状貫入岩：紀伊半島，尾熟一熊野地域の熊野 酸性火成岩類の地質, 地質学雑誌, 第113巻, 第 7 号, pp296-309.

7）鈴木隆介（1997）：建設技術者のための地形読図入門，第 1 巻 読図の基礎, 古今書院, $122 \mathrm{p}$.

8）土木学会岩盤力学委員会（1992）：軟岩評価一調査・設計 · 施工への適用一，第 1 刷, 社団法人土木学会, $228 \mathrm{p}$.

9）地盤調査法改訂編集委員会（2009）：地盤材料試験の方法と
解説，第 1 刷，社団法人地盤工学会，pp.53-59，450.

10）鳥居成幸 · 奥田哲也・高橋康三 ·橋倉清和（1998）：三重県 内に扔ける露水の性状について (第 1 報), 三重県環境科学 センター研究報告, 第18号, pp.45-49.

11）和歌山県（2012）：平成24年度 公共用水域及び地下水の水質 測定計画, 24p.

（2014年 7 月24日受付，2014年12月16日受理）

Jour. Japan Soc. Eng. Geol., Vol.55, No.6, pp.317-324, 2015

\title{
The Feature of the Debris Disaster in Kumano Acidic Rocks, Mie Prefecture, Caused by 2011 Typhoon No.12
}

\author{
Masaki ISHIKAWA, Toshinori SAKAI, Kenji OKAJIMA, Tatsuo KONEGAWA, \\ Yasushi KATAOKA, Kazuyuki SAKAGUCHI, Masashi NAKATANI, \\ Kenji HASEGAWA, Kenji HAYASHI and Tsunehiko YOSHII
}

Abstract

In the Higashi-Kishu area of Mie prefecture, many slope failures occurred by the typhoon No.12 which attacked 2011. As a result of examining the situation of landslides, based on the aerial photographs, geological maps, and DEM, about $90 \%$ of 290 landslides had occurred in the Kumano acidic rock area.

Many landslides were concentrated on slopes directed from southwest to southeast. The gradient of slopes concentrated 30 to 40 degrees with the Kumano acidic rock south block, 35 to 45 degrees with the Kumano acidic rock north block. And, the slope forms before failures consisted of valley-type slopes (47\%), straight slopes (48\%), and ridge-type slopes $(5 \%)$. As a result of field work, landslides had occurred at grade DL (strongly weathered saprolite) and/or grade DM (moderately weathered granitoid) or the boundary of a grade DH (decomposed granitoid) and talus sediment. In the collapsed places, sheeting joints were confirmed and inclination to valley side at part of columnar joints were confirmed. It was guessed that landslides generated at the remarkable part of deformation by gravity. Along joints exists grade $\mathrm{DH}$. The coefficients of permeability of grade $\mathrm{DH}$ were about from $10^{-5}$ to $10^{-6} \mathrm{~m} / \mathrm{s}$. And, the electrical conductivities of springs were as low as from 3 to $4 \mathrm{mS} / \mathrm{m}$. It was thought that shallow groundwater at rain was participating in landslides.

Key words : landslide, an aerial photograph, Kumano Acidic Rocks 